\title{
MODEL MENTAL SISWA PADA SUBPOKOK BAHASAN PERUBAHAN MATERI
}

\author{
Putu Eka Sukma Diantari ${ }^{1}$, I Wayan Suja ${ }^{2}$, I Dewa Ketut Sastrawidana ${ }^{3}$ \\ Universitas Pendidikan Ganesha \\ Singaraja, Indonesia
}

e-mail: ekasukmadiantari4397@yahoo.com, suja.undiksha01@gmail.com, ketut.sastrawidana@undiksha.ac.id

\begin{abstract}
Abstrak
Penelitian ini bertujuan mendeskripsikan dan menjelaskan profil model mental siswa serta mengidentifikasi faktor-faktor penyebab terbentuknya model mental alternatif siswa pada subpokok bahasan perubahan materi di SMP Negeri 2 Singaraja. Penelitian ini menggunakan pendekatan mix methods jenis sekuensial. Pengumpulan data dilakukan dengan observasi, pemberian tes diagnostik dua tingkat (two-tier), dan wawancara. Hasil penelitian menunjukkan profil model mental siswa kelas VII pada subpokok bahasan perubahan materi 5,30\% tergolong model mental ilmiah, serta $92,38 \%$ mengalami model mental alternatif, yang meliputi $69,81 \%$ memiliki model mental benar sebagian dan $22,57 \%$ memiliki model mental miskonsepsi khusus. Sedangkan sisanya, sebanyak 2,32\% tidak memberikan tanggapan. Faktor penyebab terbentuknya model mental alternatif pada pikiran siswa, meliputi minat dan motivasi belajar siswa rendah, pemaknaan konsep-konsep perubahan materi rendah, pemahaman konsep pendukung terkait perubahan materi rendah, pemahaman terhadap ketiga level kimia (level makroskopis, level submikroskopis, dan level simbolik) beserta interkoneksinya rendah, buku teks (paket) yang digunakan kurang lengkap, dan strategi mengajar yang diterapkan oleh guru tidak tepat.
\end{abstract}

Kata kunci: perubahan materi, model mental, model mental alternatif.

\section{Abstract}

This research was aimed to describe and explain the profile of mental model students and identify the factors that cause the formation of an alternative mental model students on the subject of material changes at SMP Negeri 2 Singaraja. This research is a mix methods approach, type sequential. Data collection was carried out by observation, giving two-tier diagnostic tests, and interviews. The results showed the profile of mental class VII grade students on the subject of material change $5.30 \%$ classified as a scientific mental model, and $92.38 \%$ experienced an alternative mental model, which included $69.81 \%$ having a partially correct mental model and $22.57 \%$ having special mental misconception models. While the rest, as much as $2.32 \%$ did not give a response. Factors that cause the formation of alternative mental models on students minds, including low interest and student learning motivation, meaning concepts of low material change, understanding of supporting concepts related to low material changes, understanding of all three chemical levels 
(macroscopic level, submicroscopic level, and symbolic level) along with the low interconnection, the textbook (package) used is incomplete, and the teaching strategy applied by the teacher is not appropriate.

Keywords: change materials, mental model, alternative mental model

\section{PENDAHULUAN}

IImu kimia merupakan bagian dari ilmu pengetahuan alam (IPA) yang secara khusus mempelajari tentang struktur, susunan, sifat, dan perubahan materi, serta energi yang menyertai setiap perubahannya (Zydny et al., 2015). Konsep-konsep dalam ilmu kimia melibatkan tiga level kimia, yaitu level makroskopis, submikroskopis, dan simbolik yang saling berhubungan satu dengan yang lainnya (Jansoon et al., 2009). Pemahaman yang tepat tentang konsep kimia dapat tercapai jika siswa mampu membangun interkoneksi ketiga level kimia. Pemahaman siswa terhadap ketiga level kimia dan interkoneksinya diungkapkan sebagai model mental (Handayanti et al., 2015). Model mental merupakan representasi internal individu terhadap suatu objek, ide-ide atau sebuah proses selama kognitifnya bekerja untuk memberikan alasan, menjelaskan, menerangkan, atau memprediksikan suatu fenomena, serta menguji ide baru dan menyelesaikan suatu masalah (Wiji et al., 2014). Pembentukan model mental dipengaruhi oleh pengalaman dan pengetahuan awal pebelajar, sikap dan keyakinan mereka, serta persoalan- persoalan yang dihadapinya (Suja, 2015). Hal ini juga didukung oleh Halim et al. (2013) yang menyatakan bahwa ketiga level representasi berdampak pada model mental siswa. Salah satu materi kimia SMP yang mencakup tiga level representasi kimia adalah perubahan materi. Perubahan materi adalah kajian penting dalam ilmu kimia, terutama ketika menelusuri materi dan mekanisme perubahannya. Pemahaman peserta didik terhadap materi ini akan menjadi dasar bagi mereka untuk mempelajari konsep- konsep kimia lain yang lebih kompleks.

Realita di sekolah menunjukkan bahwa siswa masih mengalami kesulitan dalam memahami konsep-konsep dasar kimia khususnya perubahan materi. Yoni et al. (2017) menyatakan bahwa model mental siswa kelas $X$ tentang konsep- konsep dasar kimia pada kurikulum sains SMP adalah $6,44 \%$ model mental ilmiah dan $93,56 \%$ adalah model mental alternatif. Selain itu, Iriyanti (2012) menyatakan bahwa sekitar $32,4 \%$ siswa di kelas VII mengalami miskonsepsi pada materi perubahan kimia dan fisika. Hal serupa juga dilaporkan Nurcahyani (2012) bahwa siswa masih kurang paham konsep dalam mempelajari materi perubahan kimia dan fisika. Pemahaman konsep sangat penting karena dengan memahami konsep yang benar maka siswa dapat menyerap, menguasai, dan mengingat materi yang dipelajarinya dalam waktu yang lama. Pemahaman konsep membuat siswa lebih mudah dalam menyelesaikan permasalahan karena siswa akan mampu mengaitkan serta memecahkan permasalahan tersebut dengan berbekali konsep yang sudah dipahaminya. Siswa dikatakan memiliki pemahaman yang utuh ketika siswa mampu menjelaskan permasalahan kimia sesuai dengan konsep-konsep kimia, sedangkan siswa yang tidak memiliki pemahaman yang utuh akan mengalami kesulitan dalam menyelesaikan permasalahan kimia dan dapat menimbulkan miskonsepsi. Menurut Suparno (2005) faktor-faktor penyebab siswa mengalami miskonsepsi atau model mental alternatif digolongkan menjadi lima kelompok, yaitu siswa, guru, buku teks, konteks, dan metode mengajar.

Berdasarkan studi pendahuluan disekolah, diperoleh data bahwa proses pembelajaran yang berlangsung belum mencerminkan adanya keterkaitan ketiga level representasi kimia. Guru cenderung menjelaskan materi pada level makroskopis dan simbolik. Hal ini menyebabkan siswa tidak mampu membangun interkoneksi ketiga level kimia sehingga model mental siswa cenderung dalam bentuk model mental alternatif. Tidak adanya penelitian yang berkaitan dengan model mental alternatif beserta faktor-faktor penyebab model mental alternatif menyebabkan guru belum dapat mengidentifikasi faktor-faktor penyebab terbentuknya model mental alternatif pada subpokok bahasan perubahan materi. Selain itu, didapatkan data bahwa nilai pada semester ganjil tahun ajaran 2017/2018 masih banyak yang belum mencapai nilai (KKM) pada subpokok bahasan perubahan materi yaitu di bawah 70 . Ketidaktercapaian nilai tersebut menunjukkan bahwa siswa tidak memahami konsep-konsep ilmu kimia secara utuh. Ketidakutuhan pemahaman siswa ini akan terus terbawa ke jenjang- jenjang berikutnya. Jika hal ini tidak ditanggulangi, maka akan menyulitkan siswa dalam memahami pelajaran kimia pada kelas atau jenjang pendidikan yang lebih tinggi. Bahkan, hal tersebut dapat menghambat proses pembelajaran kimia. 
Berdasarkan pemaparan di atas, peneliti tertarik melakukan penelitian mengenai profil model mental siswa serta faktor-faktor penyebab terbentuknya model mental alternatif siswa pada subpokok bahasan perubahan materi. Penelitian ini diharapkan dapat menunjukkan profil model mental serta faktor-faktor penyebab terbentuknya model mental alternatif siswa kelas VII pada subpokok bahasan perubahan materi yang mencakup ketiga level kimia dan interkoneksinya

\section{METODE}

Penelitian ini menggunakan pendekatan mix methods jenis sekuensial. Penelitian dilaksanakan di SMP Negeri 2 Singaraja pada bulan Agustus-November 2018. Metode pengumpulan data pada penelitian ini menggunakan metode observasi, pemberian tes dan wawancara Instrument yang digunakan adalah pedoman observasi, tes model mental two-tier dan pedoman wawancara. Teknik analisis data hasil tes model mental siswa dalam penelitian ini dilakukan secara deskriptif interpretatif dengan menggunakan empat katagori model mental yang dikemukakan oleh Sendur et al. (2010). Teknik ini digunakan untuk mendeskripsikan profil model mental siswa. Sedangkan data hasil wawancara dianalisis secara deskriptif interpretatif untuk mendeskripsikan faktor-faktor penyebab terbentuknya model mental alternatif. Pemeriksaan keabsahan data menggunakan triangulasi sumber dan triangulasi metode.

\section{HASIL DAN PEMBAHASAN}

Hasil jawaban siswa terhadap tes model mental menunjukkan pemahaman siswa dalam merepresentasikan ketiga level kimia, yaitu level makroskopis, level submikroskopis, level simbolik, serta interkoneksi ketiga level kimia tersebut. Pada penelitian ini model mental miskonsepsi khusus pada hal tertentu (SM) dan model mental benar sebagian (PC) dilabel sebagai model mental alternatif. Profil model mental siswa kelas VII di SMP Negeri 2 Singaraja tentang perubahan materi disajikan pada Tabel 1.

Tabel 1. Profil Model Mental Siswa

\begin{tabular}{|c|c|c|c|c|c|c|c|c|c|c|}
\hline \multirow{3}{*}{ No } & \multirow{3}{*}{ Indikator } & \multirow{3}{*}{$\begin{array}{l}\text { No } \\
\text { Soa } \\
\text { I }\end{array}$} & \multicolumn{8}{|c|}{$\begin{array}{l}\text { Model } \\
\text { Mental }\end{array}$} \\
\hline & & & \multicolumn{2}{|r|}{ SC } & \multicolumn{2}{|c|}{ PC } & \multicolumn{2}{|c|}{ SM } & \multicolumn{2}{|r|}{ NR } \\
\hline & & & $\Sigma$ & $\%$ & $\Sigma$ & $\%$ & $\Sigma$ & $\%$ & $\Sigma$ & $\%$ \\
\hline 1 & $\begin{array}{c}\text { Membedakan } \\
\text { perubahan fisika } \\
\text { dan perubahan } \\
\text { kimia } \\
\text { berdasarkan } \\
\text { struktur partikel } \\
\text { materinya. }\end{array}$ & 10 & 16 & $5,08 \%$ & 182 & $\begin{array}{c}57,78 \\
\%\end{array}$ & 84 & $\begin{array}{c}26,66 \\
\%\end{array}$ & 33 & $\begin{array}{c}10,48 \\
\%\end{array}$ \\
\hline \multirow{5}{*}{2} & \multirow{5}{*}{$\begin{array}{c}\text { Menentukan } \\
\text { terjadinya reaksi } \\
\text { kimia } \\
\text { berdasarkan } \\
\text { fenomena fisik } \\
\text { yang } \\
\text { menyertainya. }\end{array}$} & 7 & 0 & $0 \%$ & 265 & $\begin{array}{c}84,13 \\
\%\end{array}$ & 48 & $\begin{array}{c}15,24 \\
\%\end{array}$ & 2 & $0,63 \%$ \\
\hline & & 5 & 0 & $0 \%$ & 281 & $\begin{array}{c}89,21 \\
\%\end{array}$ & 34 & $\begin{array}{c}10,79 \\
\%\end{array}$ & 0 & $0 \%$ \\
\hline & & 8 & 4 & $1,27 \%$ & 198 & $\begin{array}{c}62,86 \\
\%\end{array}$ & 104 & $\begin{array}{c}33,01 \\
\%\end{array}$ & 9 & $2,86 \%$ \\
\hline & & 3 & 0 & $0 \%$ & 242 & $\begin{array}{c}76,83 \\
\%\end{array}$ & 73 & $\begin{array}{c}23,17 \\
\%\end{array}$ & 0 & $0 \%$ \\
\hline & & 2 & 69 & $\begin{array}{c}21,90 \\
\% \\
\end{array}$ & 218 & $\begin{array}{c}69,21 \\
\% \\
\end{array}$ & 28 & $8,89 \%$ & 0 & $0 \%$ \\
\hline \multirow{3}{*}{3} & \multirow{3}{*}{$\begin{array}{l}\text { Menentukan } \\
\text { terjadinya } \\
\text { perubahan fisika } \\
\text { berdasarkan ciri- } \\
\text { ciri fisik yang } \\
\text { menyertainya. }\end{array}$} & 6 & 1 & $0,32 \%$ & 218 & $\begin{array}{c}69,21 \\
\%\end{array}$ & 95 & $\begin{array}{c}30,15 \\
\%\end{array}$ & 1 & $0,32 \%$ \\
\hline & & 1 & 76 & $\begin{array}{c}24,13 \\
\%\end{array}$ & 211 & $\begin{array}{c}66,98 \\
\%\end{array}$ & 28 & $8,89 \%$ & 0 & $0 \%$ \\
\hline & & 4 & 1 & $0,32 \%$ & 206 & $\begin{array}{c}65,39 \\
\% \\
\end{array}$ & 107 & $\begin{array}{c}33,97 \\
\% \\
\end{array}$ & 1 & $0,32 \%$ \\
\hline
\end{tabular}




\begin{tabular}{cccccccccc}
\hline $\begin{array}{l}\text { Menentukan } \\
\text { pengaruh } \\
\text { pemanasan } \\
\text { terhadap sifat } \\
\text { fisika zat } \\
\text { berdasarkan } \\
\text { grafik hubungan } \\
\text { waktu dan suhu. }\end{array}$ & 9 & 0 & $0 \%$ & 178 & $\begin{array}{c}56,51 \\
\%\end{array}$ & 110 & $\begin{array}{c}34,92 \\
\%\end{array}$ & 27 & $8,57 \%$ \\
\hline \multicolumn{1}{c}{ Total } & 167 & $5,30 \%$ & 2199 & 69,81 & 711 & $\begin{array}{c}22,57 \\
\%\end{array}$ & 73 & $2,32 \%$ \\
\hline
\end{tabular}

Data profil model mental siswa berdasarkan persentase masing-masing kategori model mental menurut Sendur et

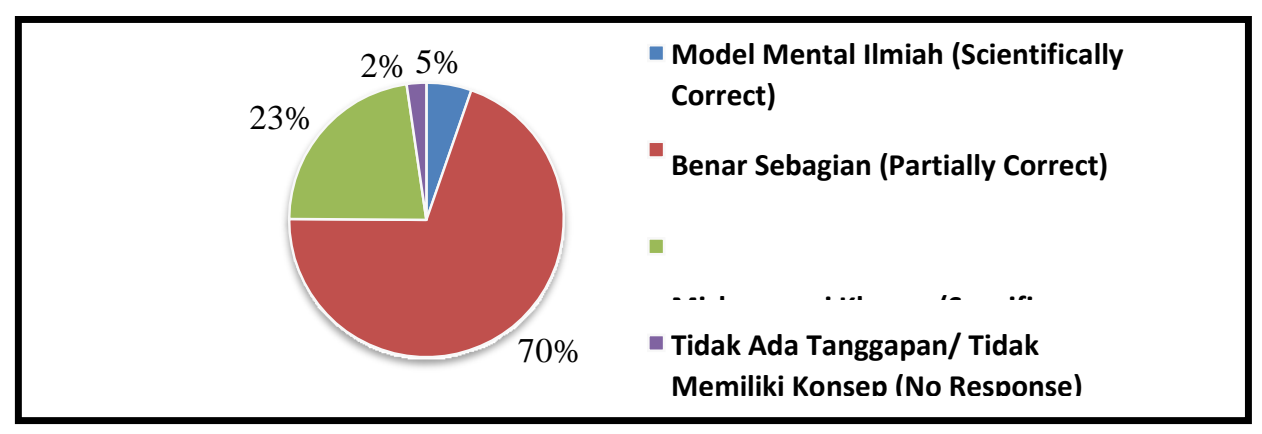

Gambar 2, Diagram Pie Profil Model Mental Siswa

Faktor-faktor penyebab model mental alternatif siswa didapat dari deskripsi model mental dan data hasil wawancara. Katagori model mental di tiap indikator yang terdapat dalam deskripsi model mental diinterpretasikan menjadi faktor-faktor penyebab munculnya model mental alternatif. Rangkuman hasil interpretasi disajikan pada Tabel 2.

Tabel 2. Rangkuman Deskripsi Faktor Penyebab Model Mental Alternatif dari Interpretasi Deskripsi Model Mental

\begin{tabular}{|c|c|c|}
\hline No. & $\underset{r}{\text { Indikato }}$ & Faktor Penyebab Model Mental Alternatif \\
\hline 1. & $\begin{array}{l}\text { Membedakan perubahan fisika } \\
\text { dan perubahan kimia berdasarkan } \\
\text { struktur partikel materinya. }\end{array}$ & $\begin{array}{l}\text { a. Pemaknaan konsep-konsep perubahan } \\
\text { materi rendah } \\
\text { b. Pemahaman siswa terhadap ketiga level kimia } \\
\text { (level makroskopis, level submikroskopis, } \\
\text { dan level simbolik) beserta } \\
\text { interkoneksinya rendah }\end{array}$ \\
\hline 2. & $\begin{array}{l}\text { Menentukan terjadinya reaksi } \\
\text { kimia berdasarkan fenomena } \\
\text { fisik yang menyertainya. }\end{array}$ & $\begin{array}{l}\text { a. Pemahaman konsep pendukung } \\
\text { terkait perubahan materi rendah } \\
\text { b. Pemaknaan konsep-konsep perubahan } \\
\text { materi rendah } \\
\text { c. Pemahaman siswa terhadap ketiga level } \\
\text { kimia (level makroskopis, level } \\
\text { submikroskopis, dan level simbolik) } \\
\text { beserta interkoneksinya rendah }\end{array}$ \\
\hline
\end{tabular}

3. Menentukan terjadinya perubahan fisika berdasarkan ciri-ciri fisik yang menyertainya. a. Pemaknaan konsep-konsep perubahan materi rendah.

b. Pemahaman siswa terhadap ketiga level kimia (level makroskopis, level submikroskopis, dan level simbolik) beserta interkoneksinya rendah 


\begin{tabular}{ll}
\hline Menentukan pengaruh & a. Pemaknaan konsep-konsep perubahan \\
pemanasan terhadap sifat fisika & materi rendah. \\
zat berdasarkan grafik & b. Pemahaman siswa terhadap ketiga level \\
hubungan waktu dan suhu. & $\begin{array}{l}\text { kimia (level makroskopis, level } \\
\text { submikroskopis, dan level simbolik) } \\
\text { beserta interkoneksinya rendah. }\end{array}$ \\
\hline
\end{tabular}

Hasil wawancara turut diinterpretasi menjadi faktor penyebab model mental alternatif. Penginterpretasian ini menghasilan enam faktor penyebab model mental alternatif. Rangkuman deskripsi faktor penyebab model mental alternatif dari interpretasi informasi hasil wawancara dapat dilihat pada Tabel 3.

Tabel 3. Rangkuman Deskripsi Faktor Penyebab Model Mental Alternatif dari Interpretasi Informasi Hasil Wawancara

\begin{tabular}{|c|c|c|}
\hline No. & $\underset{i}{\operatorname{Tnformas}}$ & Faktor Model Mental Alternatif \\
\hline 1. & $\begin{array}{l}\text { a. Siswa kurang tertarik mempelajari kimia. } \\
\text { b. Siswa tidak merespon dengan baik pertanyaan } \\
\text { yang diberikan oleh guru. }\end{array}$ & Minat belajar kimia siswa rendah \\
\hline 2. & $\begin{array}{l}\text { a. Siswa kurang memiliki kesadaran untuk } \\
\text { belajar dan rasa ingin tahu siswa rendah. } \\
\text { b. Siswa kurang melakukan persiapan } \\
\text { sebelum mengikuti pembelajaran. }\end{array}$ & $\begin{array}{l}\text { Motivasi belajar kimia siswa } \\
\text { rendah }\end{array}$ \\
\hline 3. & $\begin{array}{l}\text { a. Materi yang terdapat pada buku teks (paket) } \\
\text { kurang } \\
\text { lengkap. }\end{array}$ & $\begin{array}{l}\text { Buku teks (paket) yang digunakan } \\
\text { kurang lengkap }\end{array}$ \\
\hline 4. & $\begin{array}{l}\text { a. Guru kurang menekankan konsep-konsep } \\
\text { materi yang penting dalam pembelajaran. } \\
\text { b. Guru kurang mampu meningkatkan motivasi } \\
\text { belajar siswa dengan metode mengajar yang } \\
\text { digunakan. }\end{array}$ & Strategi mengajar yang tidak tepat \\
\hline
\end{tabular}

Diagram pie profil model mental siswa pada Gambar 01 menunjukkan bahwa model mental siswa kelas VII SMP Negeri 2 Singaraja didominasi oleh model mental benar sebagian $(69,81 \%)$ dan model mental miskonsepsi khusus (22,57\%). Temuan penelitian ini menunjukkan bahwa pemahaman siswa terkait interkoneksi tiga level kimia tentang subpokok bahasan perubahan materi masih rendah, hal ini disebabkan oleh ketidakmampuan siswa dalam menjelaskan pada level submikroskopis. Ketidakpahaman siswa dalam mengaitkan ketiga level kimia menyebabkan tidak utuhnya pemahaman siswa sehingga memiliki model mental alternatif.

Pada indikator pertama, berkaitan dengan membedakan perubahan fisika dan perubahan kimia berdasarkan struktur partikel materinya, sebagian besar siswa tidak memberikan tanggapan (NR). Persentase tertinggi pada model mental tidak ada tanggapan disebabkan oleh ketidakpahaman siswa dalam menjelaskan level submikroskopis sehingga menyebabkan siswa tidak memberikan jawaban pada soal ini. Siswa tidak mampu menjelaskan mengapa pada kasus 1 terjadi perubahan wujud ketika air dipanaskan. Perubahan wujud zat dari cair menjadi uap air disertai perubahan jarak antar partikel air yang semakin menjauh. Namun, siswa mengalami kesulitan dalam membedakan perubahan fisika dan perubahan kimia pada level submikroskopis dan tidak mampu menjelaskan terjadinya perubahan wujud. Rendahnya pemahaman siswa pada level submikroskopis menyebabkannya tidak mampu menuliskan rumus molekul air secara simbolik.

Temuan Junarti et.al (2018) menyatakan, bahwa siswa masih mengalami kesulitan dalam memahami materi perubahan fisika dan perubahan kimia. Junarti et al. (2018) juga menambahkan bahwa siswa masih banyak yang keliru membedakan perubahan fisika dan perubahan kimia. Selain itu, Laliyo (2011) juga menyatakan, bahwa siswa cenderung kesulitan untuk memahami atau menjelaskan konsep perubahan wujud zat. Bahkan penelitian Laliyo (2011) menunjukkan, bahwa kesulitan siswa dalam memahami perubahan wujud dan sifat materi juga dipengaruhi oleh konsepsi siswa yang rancu dan mengganggu proses kontruksi pemahaman konsep yang sesuai dengan konsep kimiawan.

Pada indikator kedua, tentang pemahaman siswa dalam penentuan terjadinya reaksi kimia berdasarkan ciri-ciri fisik zat, distribusi model mental benar sebagian (PC) menyumbangkan 
persentase tertinggi. Kondisi itu disebabkan oleh rendahnya pemahaman siswa dalam menjawab soal dan menjelaskan jawaban baik pada level submikroskopis maupun level simbolik sehingga memiliki model mental benar sebagian. Siswa tidak mampu menjelaskan, mengapa ketika asam sulfat direaksikan dengan natrium hidroksida tergolong perubahan kimia dan tidak mampu menuliskan persamaan reaksinya. Secara keilmuan, pada level submikroskopis, ion-ion $\mathrm{H}^{+}$dari asam sulfat akan bereaksi dengan ion-ion $\mathrm{OH}^{-}$dari natrium hidroksida menghasilkan molekulmolekul air. Reaksi antara asam sulfat dan natrium hidroksida tergolong reaksi eksoterm (melepaskan kalor), sehingga ketika bereaksi akan menimbulkan panas yang dapat dirasakan pada tabung reaksi. Hal ini menunjukkan bahwa pemahaman siswa masih rendah mengenai reaksi kimia. Rendahnya pemahaman siswa menyebabkannya tidak mampu menuliskan persamaan reaksi kimia secara simbolik.

Penelitian Ahtee et al. (2007) menyatakan, bahwa siswa masih belum paham tentang reaksi kimia. Hal ini sejalan dengan penelitian Fatmawati et al. (2014) yang menyatakan, bahwa siswa mengalami kesulitan dalam materi persamaan reaksi, sehingga siswa tidak dapat menyetarakan persamaan reaksi dengan tepat.

Pada indikator yang ketiga, pemahaman siswa dalam penentuan terjadinya perubahan fisika berdasarkan ciri-ciri fisik zat, sebanyak 5,30\% model mental siswa dalam bentuk model mental benar secara keilmuan (SC). Kondisi ini menunjukkan bahwa sebagian siswa mampu menginterpretasikan ketiga level kimia. Secara keilmuan, ketika memasak air maka akan terjadi perubahan wujud zat dari cair menjadi gas. Perubahan wujud zat pada air menyebabkan jarak antar partikel air akan berubah. Ketika wujudnya cair jarak antar partikel air lebih rapat, apabila wujudnya berubah menjadi gas maka jarak antar partikel air juga akan berubah menjadi semakin renggang. Jawaban siswa pada level makroskopis dan submikroskopis sesuai secara keilmuan. Pada level simbolik, gambar molekul air yang siswa buat masih kurang tepat. Meskipun demikian, jarak antar partikel air dalam wujud cair ke gas sudah dapat ditafsirkan memili makna sama, sehingga dikatakan sesuai secara keilmuan. Temuan ini sejalan dengan penelitian $\mathrm{Wu}$ et al. (2001) yang menyatakan, bahwa tidak dimilikinya pemahaman konsep secara utuh oleh siswa salah satunya disebabkan oleh lemahnya kemampuan siswa dalam menafsirkan penjelasan dari bentuk simbolik ke dalam bentuk submikroskopis dan sebaliknya.

Pada indikator keempat, tentang kompetensi siswa untuk menentukan pengaruh pemanasan terhadap sifat fisika zat berdasarkan grafik hubungan waktu dan suhu, distribusi model mental miskonsepsi khusus (SM) menyumbangkan persentase sebanyak $22,57 \%$. Kondisi itu disebabkan oleh ketidakpahaman siswa dalam menjawab soal dan menjelaskan jawaban baik pada level makroskopis, level submikroskopis maupun level simbolik. Siswa berpendapat bahwa perubahan suhu air akan terus meningkat apabila dipanaskan secara terus menerus di dalam ruang tertutup. Jawaban ini tidak benar secara keilmuan, selain itu siswa juga tidak mampu memberikan penjelasan pada level submikroskopis dan simbolik sehingga siswa memiliki model mental miskonsepsi khusus.

Secara keilmuan, ketika air dipanaskan secara terus menerus maka panas yang diberikan akan meningkatkan energi kinetik molekul-molekul air, sehingga temperaturnya semakin meningkat sampai mencapai suhu $100^{\circ} \mathrm{C}$ (tekanan $1 \mathrm{~atm}$ ). Pada suhu $100^{\circ} \mathrm{C}$ panas yang diberikan digunakan untuk perubahan wujud air dari cair menjadi uap air, sehingga tidak terjadi perubahan suhu (suhu tetap). Energi panas yang diberikan dipergunakan untuk memutuskan ikatan antar molekul-molekul air, sehingga jarak antar molekulnya semakin jauh, sampai terjadi perubahan wujud menjadi gas. Setelah seluruh air berubah menjadi uap air, energi panas yang diberikan dipergunakan untuk meningkatkan suhu (energi kinetik molekul) sehingga suhu semakin meningkat. Hal ini menunjukkan, bahwa siswa masih belum paham konsep perubahan wujud zat. Ketidakpahaman menyebabkan siswa tidak mampu menjelaskan jawabannya pada level makroskopis, level submikroskopis, maupun level simbolik. Temuan ini sejalan dengan hasil penelitian Laliyo (2011), bahwa siswa cenderung kesulitan untuk memahami atau menjelaskan konsep perubahan wujud zat. Kondisi ini sejalan dengan penelitian Yoni et al. (2017), yang menunjukkan bahwa sebanyak $93,56 \%$ siswa mengalami model mental alternatif tentang konsepkonsep dasar kimia pada Kurikulum Sains SMP.

Dari penjelasan di atas, persentase model mental alternatif lebih besar daripada model mental ilmiah pada setiap butir indikator model mental. Terjadinya model mental alternatif disebabkan oleh beberapa faktor yang dikelompokkan menjadi dua faktor, yaitu faktor eksternal dan faktor internal (Suja, 2015). Faktor eksternal merupakan faktor yang berasal dari luar diri siswa, yaitu buku-buku teks yang digunakan kurang lengkap serta strategi mengajar guru yang tidak tepat. 
Pertama, informasi yang terdapat di dalam buku teks yang digunakan oleh siswa pada saat pembelajaran kurang lengkap, sehingga siswa menggunakan tambahan buku seperti LKS. Kurangnya sarana yang dibutuhkan siswa berpeluang menimbulkan rasa malas pada diri siswa dalam mencari informasi terkait materi yang akan dipelajari. Selain itu, informasi minim yang terdapat pada buku teks siswa dapat menyebabkan miskonsepsi pada siswa. Hal ini sesuai dengan hasil penelitian Suja \& Retug (2013b) yang menyatakan, bahwa buku-buku yang digunakan sebagai sumber belajar oleh siswa berpeluang dalam menimbulkan terjadinya miskonsepsi.

Kedua, strategi mengajar yang digunakan guru kurang mampu meningkatkan motivasi belajar siswa. Selain itu, kurangnya penekanan konsep dasar dalam pembelajaran juga menyebabkan siswa terkadang hanya sekedar menghafal materi tanpa mengetahui konsepnya. Oleh karena itu, penggunaan strategi mengajar hendaknya dapat disesuaikan dan divariasikan sehingga mampu mengakomodasi kemampuan dan gaya belajar siswa yang berbeda-beda. Hal ini sependapat dengan West \& Marek (dalam Lin \& Chiu, 2007) yang menyatakan, bahwa strategi pengajaran yang tidak tepat dan guru yang mengalami konsepsi alternatif dapat menghasilkan konsepsi alternatif.

Faktor internal adalah faktor yang berasal dari dalam diri siswa. Pemahaman siswa terhadap ketiga level kimia beserta interkoneksinya sangat erat dengan model mental siswa. Terbentuknya model mental alternatif disebabkan oleh faktor-faktor berikut. Pertama, minat belajar siswa yang rendah. Berdasarkan hasil wawancara, siswa memang tidak memiliki minat untuk belajar kimia sehingga kebanyakan malas belajar dan menganggap pelajaran IPA sulit untuk dipahami. Hal ini diperkuat dengan pernyataan guru IPA kelas VII yang menyatakan bahwa minat belajar siswa dalam mengikuti pembelajaran kurang. Minat belajar memiliki pengaruh yang besar terhadap proses pembelajaran karena apabila bahan pelajaran yang dipelajari tidak sesuai dengan minat, siswa tidak akan belajar dengan baik. Hasil penelitian Sapuroh (2010) menyatakan, bahwa minat siswa menjadi salah satu aspek dominan yang memengaruhi kesulitan belajar siswa. Dengan demikian, rendahnya minat belajar siswa dapat menjadi faktor terbentuknya model mental alternatif siswa dalam belajar kimia.

Faktor internal kedua adalah motivasi belajar yang rendah. Kebanyakan siswa tidak memiliki waktu khusus untuk belajar setiap hari dan cenderung belajar apabila akan ada ulangan atau tes. Selain itu, keingintahuan siswa terhadap subpokok bahasan perubahan materi sangat rendah. Beberapa siswa mengatakan hanya bertanya kepada teman apabila tidak mengerti mengenai materi pelajaran dan tidak bertanya kepada guru meskipun siswa belum memahami materi tersebut. Guru IPA kelas VII juga menyatakan hal serupa bahwa siswa bersikap pasif ketika guru bertanya mengenai materi yang belum dipahami di awal pembelajaran. Ketika guru bertanya mengenai materi yang belum dipahami di akhir pembelajaran, siswa juga cenderung diam dan tidak merespon.

Motivasi belajar memiliki hubungan yang erat dengan perilaku siswa di sekolah. Motivasi belajar dapat mengarahkan siswa untuk mempelajari sesuatu yang baru. Menurut Sumiati (2007), motivasi belajar memegang peran penting terhadap pencapaian hasil, tanpa motivasi belajar siswa tidak dapat belajar dengan baik. Siswa yang memiliki motivasi tinggi akan menunjukkan perilaku, yaitu keinginan mendalami materi, ketekunan dalam mengerjakan tugas, keinginan berprestasi, dan keinginan untuk maju (Danar, 2012). Dengan demikian, rendahnya motivasi belajar siswa dapat menjadi faktor terbentuknya model mental alternatif siswa dalam belajar kimia.

Faktor internal ketiga adalah pemaknaan konsep siswa yang masih rendah. Siswa tidak memahami konsep- konsep perubahan materi secara menyeluruh dan hanya sekadar menghafal materi sehingga materi yang dipelajari akan lebih cepat terlupakan. Penelitian Junarti et al. (2018) menunjukkan, bahwa siswa masih mengalami kesulitan dalam memahami materi perubahan fisika dan perubahan kimia. Bahkan, siswa masih banyak keliru membedakan perubahan fisika dan perubahan kimia. Menurut Harefa (2013), bahan subjek yang dipelajari siswa haruslah bermakna. Pembelajaran bermakna terjadi apabila siswa dapat menghubungkan fenomena baru ke dalam struktur pengetahuan mereka. Pembelajaran bemakna merupakan pembelajaran yang menyenangkan yang memiliki keunggulan dalam meraup segenap informasi secara utuh sehingga dapat meningkatkan kemampuan siswa (Purnomo, 2009). Hal ini tercermin dari cara mengaitkan konsep baru yang akan dipelajari dengan konsep yang sudah dimiliki oleh siswa. Cara pengkaitan ini sebisa mungkin dekat dengan fakta-fakta di sekitar siswa sehingga mudah untuk dipahami. Dengan demikian, pemaknaan konsep siswa yang rendah dapat menjadi faktor terbentuknya model mental alternatif siswa dalam belajar kimia.

Faktor internal keempat yang menyebabkan terbentuknya model mental alternatif siswa adalah pemahaman konsep pendukung perubahan materi siswa masih rendah. Pemahaman 
yang rendah pada konsep pendukung ini menyebabkan siswa kesulitan dalam memahami dan menyelesaikan soal-soal perubahan materi. Salah satu karakteristik ilmu kimia adalah bersifat kompleks (kronologis), artinya konsep-konsep kimia saling berhubungan. Untuk mempelajari suatu materi dalam ilmu kimia dibutuhkan pemahaman terhadap beberapa materi kimia lainnya. Materi-materi pelajaran dalam semua bidang, termasuk bidang kimia memiliki keterkaitan satu dengan yang lain. Oleh karena itu, pemahaman suatu materi tidak bisa lepas dari konsep- konsep yang telah dipelajari sebelumnya. Dengan demikian pemaknaan konsep pendukung perubahan materi yang rendah dapat menjadi faktor terbentuknya model mental alternatif siswa dalam belajar kimia.

Faktor internal kelima yang menyebabkan terbentuknya model mental alternatif siswa adalah rendahnya pemahaman siswa terhadap ketiga level kimia (level makroskopis, level submikroskopis, dan level simbolik) beserta interkoneksinya. Menurut teori

Piaget, pada usia 6 - 12 tahun perkembangan kognitif seseorang memasuki tahap operasi konkret. Siswa cenderung masih menerapkan logika berpikir pada barang-barang konkret, belum bersifat abstrak. Siswa masih mempunyai kesulitan untuk menyelesaikan masalah yang memiliki banyak variabel. Data tersebut sesuai dengan pendapat Jansoon et al. (2009), yang menyatakan bahwa pemahaman siswa dalam merepresentasikan ketiga level kimia masih tergolong rendah

Hal yang sama juga ditemukan Wu et al. (2001), bahwa tidak dimilikinya pemahaman konsep secara utuh oleh siswa salah satunya disebabkan oleh lemahnya kemampuan siswa dalam menafsirkan penjelasan dari bentuk simbolik ke dalam bentuk submikroskopis dan sebaliknya. Selain itu, penelitian yang dilakukan oleh Suja \& Retug (2013a) pada siswa kelas XI serta penelitian Suja \& Retug (2013b) pada siswa kelas XII juga menunjukkan ketidakutuhan pemahaman siswa tentang tiga level representasi dan interkoneksinya pada pembelajaran kimia. Seluruh hasil penelitian tersebut memberikan hasil yang sama, yaitu rendahnya pemahaman siswa terkait representasi ketiga level kimia beserta interkoneksinya menyebabkan ketidakutuhan pemahaman siswa sehingga memiliki model mental alternatif.

\section{SIMPULAN DAN SARAN}

Dari Berdasarkan hasil penelitian dan pembahasan yang telah diuraikan, dapat disimpulkan bahwa profil model mental siswa pada subpokok bahasan perubahan materi sebanyak $5,30 \%$ tergolong model mental ilmiah, serta $92,38 \%$ siswa mengalami model mental alternatif, yang meliputi $69,81 \%$ memiliki model mental benar sebagian dan 22,57\% memiliki model mental miskonsepsi khusus. Sedangkan, sisanya sebanyak 2,32\% tidak memberikan tanggapan. Tingginya persentase siswa mengalami model mental alternatif disebabkan oleh pemahaman siswa terkait representasi ketiga level kimia beserta interkoneksinya pada subpokok bahasan perubahan materi tergolong rendah. Faktor penyebab model mental alternatif siswa pada subpokok bahasan perubahan materi dibagi dua,yaitu faktor internal dan eksternal. Faktor internal meliputi minat dan motivasi belajar yang rendah, pemaknaan konsep-konsep perubahan materi rendah, pemahaman konsep pendukung terkait perubahan materi rendah, dan pemahaman terhadap ketiga level kimia (level makroskopis, level submikroskopis, dan level simbolik) beserta interkoneksinya rendah. Sedangkan, faktor eksternal meliputi buku teks (paket) yang digunakan kurang lengkap dan strategi mengajar yang diterapkan oleh guru tidak tepat.

Berdasarkan hasil yang telah dicapai pada penelitian ini, saran yang dapat diberikan adalah bagi guru-guru IPA diharapkan dalam menjelaskan konsep- konsep dasar kimia di SMP tidak hanya mengajar dengan memberi penekanan pada level makroskopis dan simbolik, tetapi juga dilengkapi dengan level submikroskopis. Pengenalan level submikroskopis akan sangat membantu siswa dalam mempelajari konsep-konsep kimia pada jenjang pendidikan yang lebih tinggi. Selain itu, buku ajar IPA yang dipergunakan pebelajar hendaknya dikemas menarik, mencakup ketiga level kimia yaitu level makroskopis, level submikroskopis, dan level simbolik, serta dilengkapi dengan manfaat setiap konsep yang akan dipelajari pebelajar.

\section{DAFTAR RUJUKAN}

Ahtee, M. \& Varjola, I. 2007. Students Understanding of Chemical Ekstrinsik Siswa dengan Prestasi Belajar Siswa Kelas X Kompetensi Keahlian Teknik Audio Video SMK Ma'arif 1 Wates. Yogyakarta: Universitas Negeri Yogyakata. Diperoleh dari http://eprints.uny.ac.id/7516/. 
Fatmawati., Papuntungan. M., \& Rakhmawaty. A. 2014. Identifikasi Kesulitan Belajar Siswa pada Materi Persamaan Reaksi kelas X dan XI IPA MAN Batudaa. E-jurnal Fakultas MIPA Universitas Negeri Gorontalo.

Halim, N. D. A., Ali, M. B., \& Yahaya, N. 2013. "Mental Model in Learning Chemical Bonding: A Preliminary Study". Journal Procedia - Social and Behavioral Sciences. 97: 224228.

Handayanti, Y., Setiabudi, A., \& Nahadi. 2015. "Analisis Profil Model Mental Siswa SMA pada Materi Laju Reaksi". Jurnal Penelitian dan Pembelajaran IPA. 1(1): 107-122, e-ISSN 2477-2038.

Harefa, A. O. 2013. "Penerapan Teori Pembelajaran Ausebel dalam Pembelajaran". Warta Dharmawangsa. 36: 43-55.

Iriyanti, N. P., Mulyani, S., \& Ariani, S. R.

D. 2012. "Identifikasi Miskonsepsi pada Materi Pokok Wujud Zat Siswa Kelas VII SMP Negeri 1 Bawang Tahun Ajaran 2009/2010". Jurnal Pendidikan Kimia. 1(1): 8- 13.

Jansoon, N., Richard, K. C., \& Somsook,

E. 2009. "Understanding Mental Models of Dilution In Thai Students". International Journal of Environmental \& Science Education. 4(2): 147-168.

Junarti., Enawaty, E., \& Sartika, R. P. 2018. "Deskripsi Pemahaman Konsep Siswa pada Materi Perubahan Kimia dan Fisika di Kelas VII SMP". Jurnal Pendidikan dan Pembelajaran. 7(1): 1-8.

Nurcahyani, N. 2012. "Efektivitas Metode Pembelajaran Student Teams Achievement Divisions (STAD) Berbasis Science Environment Technology And Society (SETS) Berbantuan Macromedia Flash terhadap Prestasi Belajar Siswa pada Materi Pokok Perubahan Fisika Dan Kimia". Jurnal Pendidikan Kimia. 1: 19-25.

Purnomo, Arif. 2009. Pengembangan Asessmen. Semarang: PPG UNNES Semarang.

Sapuroh, S. 2010. Analisis Kesulitan Belajar Siswa dalam Memahami Konsep Biologi pada Konsep Monera di MAN Serpong Tanggerang. Skripsi tidak diterbitkan. Jakarta: Universitas Islam Negeri Syarif Hydayatullah

Sendur, G., Toprak, M., \& Pekmez, E.S. 2010. "Analyzing of Students' Misconceptions About Chemical Equilibrium". Paper on International Conference on New Trends in Education and Their Implications. Antalya-Turkey.

Suja, I W, \& Retug, N., 2013a. Profil Konsepsi Kimia Siswa Kelas XI di Kota Singaraja.Prosiding Senari (Seminar Nasional Riset Inovatif) Lembaga Penelitian UNDIKSHA. 1: (172179), ISSN 2339-1553.

Tersedia pada

http://lemlit.undiksha.ac.id

Suja, I W, \& Retug, N., 2013b. Konsepsi Kimia Siswa Kelas XII di Kota Singaraja. Prosiding Seminar Nasional FMIPA UNDIKSHA III

Tahun 2013. Tersedia pada http://ejournal.undiksha.ac.id (diakses tanggal 20 Juli 2017).

Suja, I W. 2015. "Model Mental Mahasiswa Calon Guru Kimia dalam Memahami Bahan Kajian Stereokimia". Jurnal Pendidikan Indonesia. 4(2): 625-638.

Bandung: CV Wacana Prima.

Suparno, Paul. 2005. Miskonsepsi dan Perubahan Konsep Pendidikan Fisika. Jakarta: Grasindo.

Wiji., Liliasari., Sopandi W., dan Martoprawiro, M. A. K. 2014. "Kemampuan Berpikir Logis dan Model Mental Kimia Sekolah Mahasiswa Calon Guru”. Jurnal Cakrawala Pendidikan. 
$33(1): 147-$

156.

Yoni, A. A. I. S., Suja, I W., \& Karyasa, I

W. 2017. Profil Model Mental Siswa SMA Kelas X tentang

Konsep-konsep Dasar Kimia pada Kurikulum Sains SMP. Singaraja: Universitas Pendidikan Ganesha. Tersedia pada

http://ejournal.undiksha.ac.id (diakses tanggal 11 Juni 2018).

Zydny, R., Sopandi, W, \& Kusrijadi, A. 2015. "Gambaran Level Submikroskopik Untuk Menunjukan Pemahaman Konsep Siswa pada Materi Persamaan Kimia dan Stoikiometri". Jurnal Penelitian dan Pembelajaran IPA. 1(1): 42-59, e-

ISSN 2477-2038. 